\title{
Transmission of Food Price Volatility from International to Domestic Markets: Evidence from Africa, Latin America, and South Asia
}

\author{
Francisco Ceballos, Manuel A. Hernandez, Nicholas Minot, \\ and Miguel Robles
}

\subsection{Introduction}

The global food crisis of 2007-2008 was characterized by a sharp spike in grain and other commodity prices. These price increases have been attributed to supply shortages, increased biofuel production, reduced stock-to-use ratios, export bans by major grain exporters, and panic buying by some major importers (Gilbert 2010). Commodity prices rose rapidly again in 2010, 2011, and 2012. Since 2007, global grain markets have seen an overall increase in price volatility, which is defined as the standard deviation of monthly price returns. For example, comparing the $27-$ year period before the crisis (1980-2006) with the 4-year period during and after the crisis (2007-2010), the unconditional volatility of international prices rose by $52 \%$ for maize, $87 \%$ for rice, and $102 \%$ for wheat (Minot 2014).

To the extent that this price volatility is transmitted to markets in developing countries, it may have serious implications for farmers and low-income consumers. First, low-income consumers spend a large share of their income on food in general and on staple foods in particular, thereby making them more vulnerable to food price volatility. For instance, in some countries, such as Tanzania, Sri Lanka, and Vietnam, low-income households allocate more than $60 \%$ of their budgets to food (Seale et al. 2003). Second, food price volatility affects poor, small-scale farmers who rely on food sales for a significant part of their income and possess limited capacity for timing their sales. Third, price volatility is likely to inhibit agricultural investment and reduce agricultural productivity growth-especially in the absence of efficient risk-sharing mechanisms-with long-run implications for poor consumers and farmers.

\footnotetext{
F. Ceballos $\bullet$ M.A. Hernandez $\bullet$ N. Minot $\bullet$ M. Robles $(\bowtie)$

International Food Policy Research Institute (IFPRI), 2033 K Street NW, Washington, DC 20006, USA

e-mail: f.ceballos@cgiar.org; m.a.hernandez@cgiar.org; n.minot@cgiar.org; m.robles@cgiar.org
} 
A key question, however, is whether food price volatility in world grain markets is indeed transmitted to local markets in developing countries. If so, efforts to reduce excessive price volatility should perhaps be focused on concerted regional and international actions through the World Trade Organization or other multilateral bodies. Alternatively, if food price volatility in developing countries is mostly attributed to domestic factors, then the most effective policy remedies would likely be solutions at the local level which are targeted at the most vulnerable groups.

One approach to answering this question is to examine the transmission of prices (in levels) from world markets to local markets. ${ }^{1}$ Although it seems reasonable to assume that markets with high transmission of prices could also be characterized by high transmission of volatility, this may not necessarily be the case. For example, prices from highly volatile world markets may only be transmitted to local markets with a 1- to 6-month lag, thus insulating local markets from international turmoil and resulting in less volatile local prices. Alternatively, even if there were no direct price transmission, it would still be possible for local market volatility to be determined by the degree of uncertainty among local traders, which could be influenced by a sudden increase in the volatility on world markets.

The objective of this paper is to directly estimate the transmission of grain price volatility from world markets to local markets in developing countries. In particular, we focus on the effect of the changes in the world price of maize, rice, wheat, and sorghum on 41 domestic prices of grain products in 27 countries in Latin America, Africa, and Asia. The price data are monthly, and mostly cover the period from January 2000 to December 2013, though there is some variation in the starting and ending points. The analysis is based on a multivariate generalized autoregressive conditional heteroskedasticity $(\mathrm{MGARCH})$ model using the BEKK specification proposed by Engle and Kroner (1995). ${ }^{2}$

The main contribution of this paper is that it is one of the first studies to estimate the transmission of food price volatility from international markets to local markets across several developing countries and regions. As will be discussed later, other studies have examined the transmission of (mean) price levels from global markets to developing countries. However, studies on the transmission of price volatility have mainly focused on examining volatility dynamics across different commodities and international markets. In addition, by focusing on market interactions in terms of the conditional second moment and allowing for volatility spillovers, better insight into the dynamic price relationship of international and domestic markets can be gained.

The remainder of the paper is organized as follows. Section 13.2 provides a review of recent research on transmission of prices and volatility. Section 13.3 details the methodology used in the study. Section 13.4 describes the data. Sec-

\footnotetext{
${ }^{1}$ Section 13.2 discusses the relatively large body of research examining price transmission.

${ }^{2}$ The BEKK acronym comes from the synthetized work on multivariate GARCH models by Baba et al. (1990).
} 
tion 13.5 presents and discusses the estimation results, and Sect. 13.6 summarizes the findings and draws some conclusions for future research.

\subsection{Previous Research on Transmission of Prices and Volatility}

There is a large body of research on the transmission of prices between markets within developing countries (see Baulch 1997; Abdulai 2000; Rashid 2004; Lutz et al. 2006; Negassa and Myers 2007; Van Campenhout 2007; Myers 2008; Moser et al. 2009). Most of these studies used cointegration analysis in the form of error correction models, although some of the more recent studies applied threshold cointegration models and asymmetric response to positive and negative price shocks (e.g., Meyer and von Cramon-Taubadel 2004). Fewer studies have examined the transmission of prices from world markets to local markets. Mundlak and Larson (1992) estimated the transmission of world food prices to domestic prices in 58 countries using annual price data. They found very high rates of price transmission, but the analysis was carried out in levels rather than first differences, so the results probably reflected spurious correlation due to nonstationarity. Quiroz and Soto (1995) repeated the analysis of Mundlak and Larson (1992) using cointegration analysis and an error correction model. They found no relationship between domestic and international prices for 30 of the 78 countries examined. Conforti (2004) examined price transmission in 16 countries, including 3 in sub-Saharan Africa, using an error correction model. In general, the degree of price transmission in sub-Saharan African countries was lower than in Asian and Latin American countries. Minot (2010) analyzed the transmission of prices from world grain markets to 60 markets in sub-Saharan Africa and found a statistically significant long-term relationship in only 13 of the 62 prices examined. He also found that African rice prices are more closely linked to world markets than maize prices, presumably because most African countries are close to self-sufficiency in maize product but import a large share of their rice requirements.

Another set of studies has focused on the co-movement of world commodity prices. In their seminal paper, Pindyck and Rotemberg (1990) found "excessive co-movement" of seven commodity prices, which they attributed to herd behavior among traders in financial markets. The hypothesis of excess co-movement, however, was challenged by Deb et al. (1996) and Ai et al. (2006). These studies argued that the results obtained by Pindyck and Rotemberg suffered from misspecification and that fundamental supply and demand factors were sufficient to explain the comovement. ${ }^{3}$ In the case of international agricultural prices, Gilbert (2010) indicated that shocks to individual commodity prices are often supply related, whereas joint price movement can be explained by macroeconomic and monetary conditions.

\footnotetext{
${ }^{3}$ See Saadi (2010) for an extensive review of commodity price co-movement in international markets.
} 
Fewer studies have examined the co-movement of conditional price volatility. As noted by Gallagher and Twomey (1998), dynamic models of conditional volatility, like MGARCH models, which are widely used in empirical finance, can provide a better understanding of the dynamic price relationship between markets by evaluating volatility spillovers. Volatility transmission between commodity markets may occur through substitution effects or as a result of common underlying factors, such as uncertainty in financial markets.

Some of the recent studies that examined market interactions between agricultural commodities using MGARCH models include Le Pen and Sévi (2010), Zhao and Goodwin (2011), Hernandez et al. (2014), Beckmann and Czudaj (2014), and Gardebroek et al. (2014). Le Pen and Sévi (2010) used different multivariate models, including a factor model and a Dynamic Conditional Correlation (DCC) model, to examine the interrelationship between eight agricultural and nonagricultural commodities and find moderate co-movement in prices and volatility. Zhao and Goodwin (2011) found important volatility spillovers between corn and soybean future prices based on a BEKK model. Using both a BEKK and a DCC model, Hernandez et al. (2014) showed significant volatility spillovers within corn, wheat, and soybean futures exchanges in the United States, Europe, and Asia as well as an increase in their interdependence in recent years. Beckmann and Czudaj (2014) also showed evidence supporting short-run volatility transmission between futures prices of corn, wheat, and cotton, based on bivariate GARCH-in-mean VAR models. Lastly, Gardebroek et al. (2014) used different MGARCH models and found little evidence of price transmission in levels between corn, wheat, and soybean spot markets. However, they found significant transmission in price volatility, particularly at weekly and monthly frequencies.

\subsection{Methodology}

We followed an MGARCH approach to evaluate the dynamics of volatility in monthly price returns from major agricultural international commodities to key domestic products in Africa, South Asia, and Latin America. ${ }^{4}$ In particular, we estimated a bivariate T-BEKK model, proposed by Engle and Kroner (1995), which allowed us to model volatility transmission from international to domestic markets since the model is flexible enough to take into account both volatility spillovers and persistence across markets. ${ }^{5}$

The T-BEKK approach involves modeling both a conditional mean equation and a conditional variance equation for each price return series considered in the analysis. In our case, we defined price returns as $r_{m t}=\ln \left(p_{m t} / p_{m t-1}\right)$, where $p_{m t}$ is

\footnotetext{
${ }^{4}$ See Bauwens et al. (2006) and Silvennoinen and Teräsvirta (2009) for an extensive overview of different MGARCH models.

${ }^{5}$ The $\mathrm{T}$ acronym refers to the student's $t$ density used in the model estimation in order to better control the leptokurtic distribution of the price returns series.
} 
the price of a certain product (commodity) in market $m$ at month $t$, and $m=1$ refers to the domestic market while $m=2$ to the international market. The logarithmic transformation is a standard measure for net returns in a market and is generally applied in empirical finance to obtain a convenient support for the distribution of the error term in the estimated model.

For those cases in which the pair of price returns are not found to be cointegrated, the conditional mean equation is simply modeled as a vector autoregressive (VAR) process such that

$$
r_{t}=a_{0}+\sum_{s=1}^{k} a_{s} r_{t-s}+\varepsilon_{t}, \varepsilon_{t} \mid I_{t-1} \sim\left(0, H_{t}\right)
$$

where $r_{t}$ is a $2 \times 1$ vector of price returns for the corresponding product (commodity) in the domestic and international market at month $t$, i.e., $r_{t}=\left(\begin{array}{l}r_{1 t} \\ r_{2 t}\end{array}\right) ; a_{0}$ is a $2 \times 1$ vector of constants; $a_{s}, s=1, \ldots, k$, are $2 \times 2$ matrices of parameters capturing own and cross lead-lag relationships between markets at the mean level; and $\varepsilon_{t}$ is a $2 \times 1$ vector of innovations with zero mean, conditional on past information $I_{t-1}$, and conditional variance-covariance matrix $H_{t}{ }^{6}$ In order to determine the number of lags $(k)$, we relied on the Schwarz Bayesian Information Criterion (SBIC). The number of lags in the conditional mean equation varied between zero and two lags, with only one case requiring three lags.

For those cases where the pair of price returns are found to be cointegrated, the conditional mean equation is modeled as a vector-error correction (VEC) model such that

$$
r_{t}=a_{0}+\sum_{j=1}^{k} a_{j} r_{t-j}-\lambda \mathrm{ECT}_{t-1}+\varepsilon_{t}, \varepsilon_{t} \mid I_{t-1} \sim\left(0, H_{t}\right)
$$

where $\mathrm{ECT}_{t-1}$ is the lagged error correction term resulting from the cointegration relationship, i.e., $\mathrm{ECT}_{t-1}=\ln p_{1, t-1}-\beta_{0}-\beta_{1} \ln p_{2, t-1}$, and $\lambda$ is a $2 \times 1$ vector of parameters that measure the adjustment of each $(\log )$ price series to deviations from the long-run equilibrium.

\footnotetext{
${ }^{6}$ Other control variables were excluded from the conditional mean (and variance) equations to capture dynamic price relationships across markets in their purest form. As with any autoregressive process, the state of the process (mean or variance) in the previous period is assumed to account for all relevant information prior to the realization of the mean or variance in the current period.
} 
The conditional variance-covariance matrix $H_{t}$ at time $t$ (with one-time lag) is, in turn, given by

$$
H_{t}=C^{\prime} C+A^{\prime} \varepsilon_{t-1} \varepsilon_{t-1} A+G^{\prime} H_{t-1} G
$$

where $C$ is a $2 \times 2$ upper triangular matrix of constants $c_{i j}, A$ is a $2 \times 2$ matrix whose elements $a_{i j}$ capture the direct effect of an innovation in market $i$ on the current price return volatility in market $j$, and $\mathrm{G}$ is a $2 \times 2$ matrix whose elements $g_{i j}$ measure the direct influence of past volatility in market $i$ on the current volatility in market $j$ (persistence). If we expand Eq. (13.2), the resulting conditional variance equation for the domestic market is defined as

$$
\begin{aligned}
h_{11, t} & =c_{11}^{2}+a_{11}^{2} \varepsilon_{1, t-1}^{2}+2 a_{11} a_{21} \varepsilon_{1, t-1} \varepsilon_{2, t-1}+a_{21}^{2} \varepsilon_{2, t-1}^{2}+g_{11}^{2} h_{11, t-1} \\
& +2 g_{11} g_{21} h_{12, t-1}+g_{21}^{2} h_{22, t-1}
\end{aligned}
$$

This variance-covariance specification allows us to characterize the magnitude and persistence of volatility transmission from international to domestic markets. Moreover, similar to Gardebroek and Hernandez (2013) and Hernandez et al. (2014), we derived impulse response functions for the estimated conditional volatilities to assess how a shock or innovation is transmitted from the international market to the domestic market and obtain the elasticity of domestic price volatility with respect to international price volatility.

\subsection{Data}

We compiled a large dataset of monthly prices of maize, rice, sorghum, wheat, and wheat products for 41 markets in 27 countries. We obtained domestic price data from two sources. Our main source was the Famine Early Warning Systems Network (FEWS NET), which tracks the nominal prices of several staple food commodities across several key domestic markets on a monthly basis. This service is provided as part of their Price Bulletin product and is only available for countries in which the network has a presence-mostly African and Central American economies. Our second source was the Global Information and Early Warning System (GIEWS) of the Food and Agriculture Organization (FAO), which relies on price information from a number of local primary sources across FAO's 190 member countries. We relied on this source to obtain domestic prices in Asian, South American, and some additional Central American countries.

Out of all the price series available from these sources, we considered the domestic prices of the most important food staples in each country, which are defined as those constituting the highest share of the local diet. Moreover, prices from the main local market-generally the capital city-were chosen to be representative of each product. We also included prices observed in more than one market for a few countries (in India, for example, prices from both the Mumbai and the New Delhi markets were considered). As prices are denominated in local currency, each 
price series was converted into the US dollar using monthly exchange rates from the IMF's International Financial Statistics (IFS) database. Normalizing all prices to the US dollar allowed us to take into account the potential impact of the exchange rate on the international-domestic price transmission analysis. We excluded price series with less than 100 observations (i.e., months) or with a high number of missing or repeated values. Missing values in the remaining series were approximated through linear interpolation between the two closest available data points. Appendix Table 13.3 shows the details for each of the price series used, including its source (FEWS NET or GIEWS), the corresponding local market, whether it is a retail or a wholesale price, and its unit of measurement.

International monthly price series are compiled by the FAO International Commodity Prices database (FAOSTAT). These prices are expressed in terms of US dollars per tonne. The maize price is for No. 2 yellow maize, U.S. Gulf; the rice price is for A1 super, white broken rice, Bangkok, f.o.b.; the sorghum price is for No. 2 yellow sorghum, U.S. Gulf; and the wheat price is for No. 2 hard red winter wheat (ordinary protein), U.S. Gulf, f.o.b. Appendix Table 13.4 shows the details of each of the international price series used.

Figure 13.1 shows the evolution of international monthly prices for maize, rice, sorghum, and wheat over the 2000-2014 period. In general, prices had been rising in a relatively stable way until the spikes experienced during the food crisis of 2007-2008; price spikes were subsequently observed between 2010 and 2012. Interestingly, the figure shows a large degree of co-movement between the prices for the four commodities during the past years. The price movement of sorghum

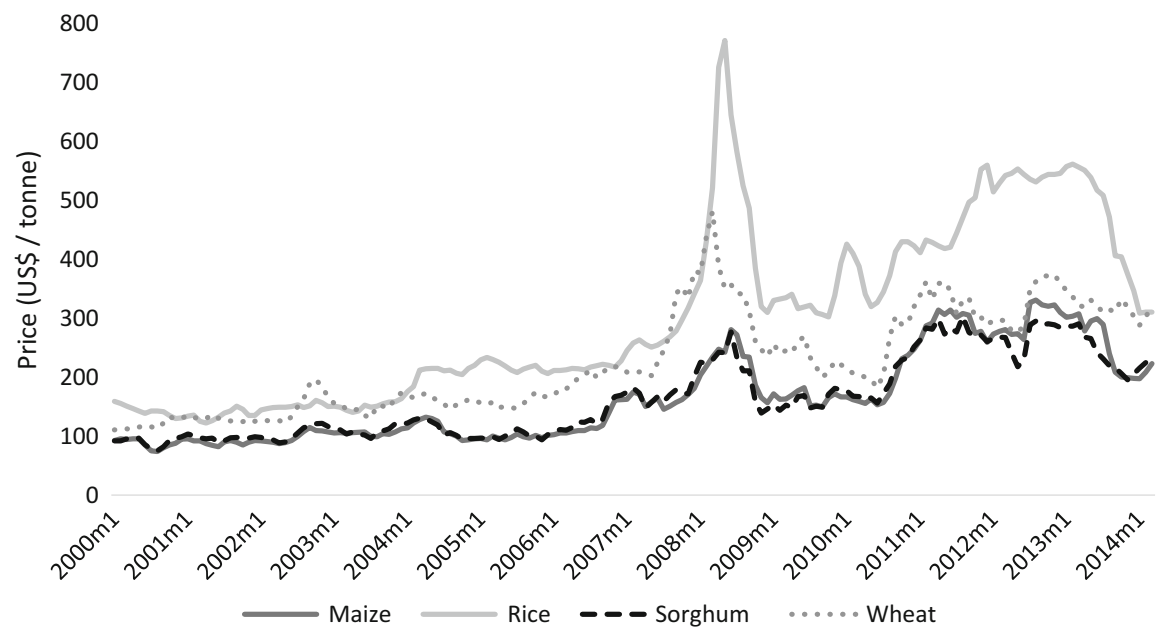

Fig. 13.1 International commodity prices-2000-2014. Note: this figure shows the evolution of the monthly international prices of maize, rice, sorghum, and wheat during the 2000-2014 period. Prices are expressed in US\$ per tonne 


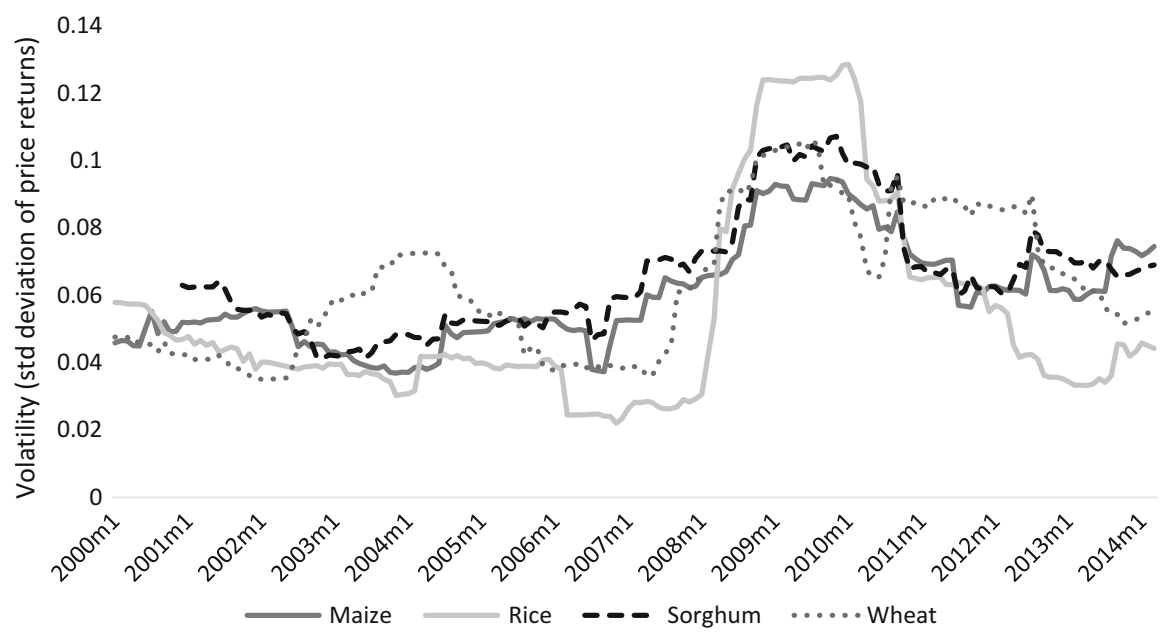

Fig. 13.2 Volatility of international grain prices (2-year moving window) -2000-2014. Note: this figure shows the evolution of the volatility of monthly international prices of maize, rice, sorghum, and wheat during the 2000-2014 period. The monthly volatility was calculated as the standard deviation of the monthly price returns observed during that month and the previous 23 months

and maize showed striking similarities; this is also true of wheat price movementthough to a lesser extent.

International prices of different food commodities also seem to co-move in terms of volatility. Figure 13.2 shows the evolution of price volatility (the standard deviation of monthly price returns) for these four commodities over a 2-year moving window from 2000 to $2014 .^{7}$ The price volatility of these commodities seems to have followed a similar pattern during most of the period of analysis, with a considerable increase during and following the 2007-2008 food crisis, followed by a decrease-even though price volatility after the decrease was still higher than prior to the crisis. This is more clearly observed in Fig. 13.3, which compares price volatility before (2000-2006) and after the crisis (2008-2014). Except for sorghum, which showed only a moderate increase, sample standard deviations for the rest of the commodities increased by more than $30 \%$ after the crisis, indicating a much higher variation (fluctuation) of international agricultural prices in recent years.

As discussed above, the main purpose of this study is to analyze volatility transmission from international to domestic markets. As a first step, it is useful to analyze the dynamics of the volatility of domestic prices vis-à-vis that of the international reference prices. Figure $13.4 \mathrm{a}-\mathrm{d}$ plots the evolution of price volatility (the standard deviation of international and domestic price returns) by commodity over a 2-year moving window, similar to Fig. 13.2. The results were mixed. In the

\footnotetext{
${ }^{7}$ For instance, the number for January 2000 reflects the standard deviation of the monthly realized price returns from February 1998 until January 2000.
} 


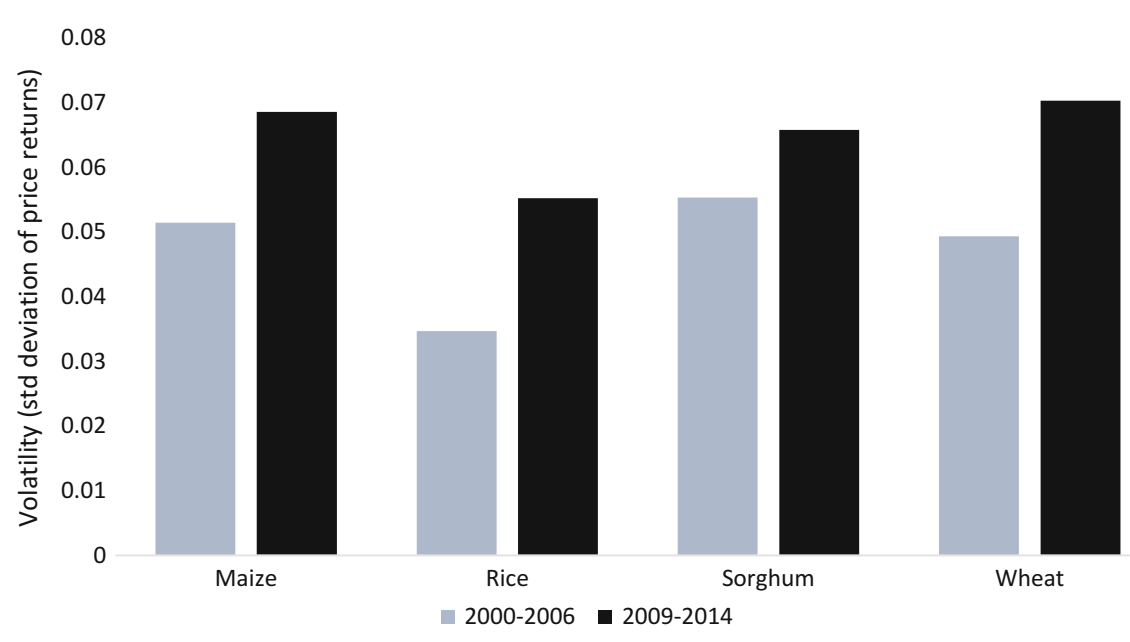

Fig. 13.3 Volatility of international grain prices before and after the 2007-2008 crisis. Note: this figure shows the volatility of monthly international prices of maize, rice, sorghum, and wheat before and after the 2007-2008 food crisis. The "before" period spans 2000-2006 while the "after" period spans 2009-2014. The volatility for each period is calculated as the standard deviation of the observed monthly price returns for each commodity

a

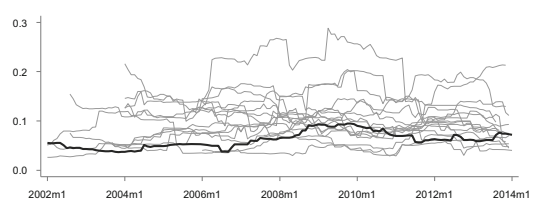

C

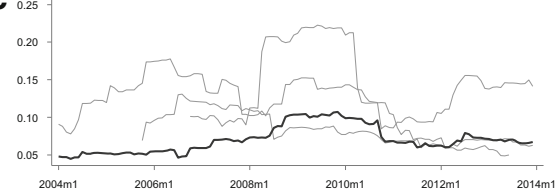

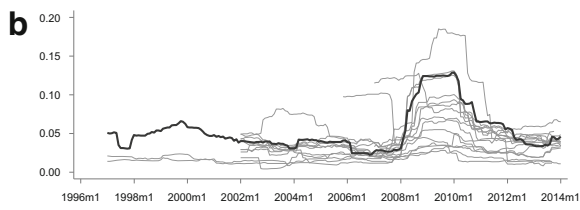

d 0.15

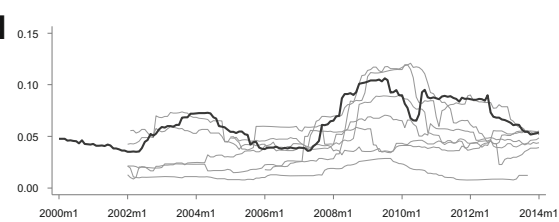

Fig. 13.4 Volatility (2-year moving window) of domestic and international prices for (a) maize, (b) rice, (c) sorghum, and (d) wheat. Note: Figures (a)-(d) show the evolution of the volatility of monthly domestic and international prices of maize, rice, sorghum, and wheat during the 2000 2014 period. The volatility for every month is calculated as the standard deviation of the monthly price returns observed during that month and the previous 23 months. The line in bold represents the volatility of each international price series

case of rice and wheat, there seems to be a substantial co-movement in the volatility of domestic and international prices, particularly in the case of rice. The volatility of international sorghum prices also showed some evidence of co-movement with the volatility of domestic sorghum-related prices. The volatility pattern of prices in domestic maize markets, in contrast, did not generally resemble the volatility pattern exhibited by international maize prices. The volatility dynamics between domestic 
Table 13.1 Summary statistics and selected normality, autocorrelation, and stationarity tests

\begin{tabular}{|c|c|c|c|c|c|}
\hline & Maize & Rice & Sorghum & Wheat & Total \\
\hline \multicolumn{6}{|l|}{ Panel A: domestic price series } \\
\hline Number of domestic price series & 16 & 15 & 3 & 7 & 41 \\
\hline Mean price returns $(\%)$ & 0.42 & 0.33 & 0.47 & 0.46 & 0.40 \\
\hline$\%$ of series with kurtosis $>3$ & 100.0 & 100.0 & 100.0 & 100.0 & 100.0 \\
\hline$\%$ of series rejecting Jarque-Bera test's $\mathrm{H}_{0}$ & 93.8 & 100.0 & 100.0 & 100.0 & 97.6 \\
\hline $\begin{array}{l}\% \text { of series rejecting Ljung-Box test's } \mathrm{H}_{0} \\
\text { on squared returns ( } 5 \text { lags) }\end{array}$ & 31.3 & 66.7 & 0.0 & 71.4 & 48.8 \\
\hline $\begin{array}{l}\% \text { of series rejecting Ljung-Box test's } \mathrm{H}_{0} \\
\text { on squared returns (10 lags) }\end{array}$ & 31.3 & 73.3 & 33.3 & 71.4 & 53.7 \\
\hline $\begin{array}{l}\% \text { of series rejecting } \mathrm{AC} \mathrm{Q} \text { test's } \mathrm{H}_{0} \text { on } \\
\text { squared returns (first lag) }\end{array}$ & 37.5 & 73.3 & 33.3 & 71.4 & 56.1 \\
\hline $\begin{array}{l}\% \text { of series rejecting AC Q test's } \mathrm{H}_{0} \text { on } \\
\text { squared returns (second lag) }\end{array}$ & 43.8 & 80.0 & 33.3 & 85.7 & 63.4 \\
\hline $\begin{array}{l}\% \text { of series rejecting ADF test's } \mathrm{H}_{0} \text { on } \\
\text { logarithm of price in levels (5 lags) }\end{array}$ & 56.3 & 13.3 & 0.0 & 57.1 & 36.6 \\
\hline $\begin{array}{l}\% \text { of series rejecting ADF test's } \mathrm{H}_{0} \text { on } \\
\text { price returns (5 lags) }\end{array}$ & 100.0 & 100.0 & 100.0 & 100.0 & 100.0 \\
\hline \multicolumn{6}{|l|}{ Panel B: international price series } \\
\hline Mean price returns $(\%)$ & 0.52 & 0.39 & 0.54 & 0.62 & \\
\hline Standard deviation of price returns $(\%)$ & 6.44 & 6.18 & 6.74 & 6.65 & \\
\hline Jarque-Bera statistic & $28.68 *$ & $273.10^{*}$ & $39.46^{*}$ & $39.37 *$ & \\
\hline Kurtosis & 4.84 & 9.15 & 5.27 & 5.11 & \\
\hline Ljung-Box statistic on squared returns (5 lags) & 1.58 & $53.74 *$ & 4.42 & 7.25 & \\
\hline Ljung-Box statistic on squared returns (10 lags) & 11.86 & $80.14 *$ & 8.71 & 11.86 & \\
\hline AC Q statistic on squared returns (first lag) & 0.09 & $0.35^{*}$ & 0.08 & $0.17 *$ & \\
\hline AC Q statistic on squared returns (second lag) & 0.03 & 0.34 & 0.01 & $0.09^{*}$ & \\
\hline ADF statistic-logarithm of price in levels (5 lags) & -1.40 & -1.58 & -1.47 & -1.78 & \\
\hline ADF statistic—price returns (5 lags) & $-5.88 *$ & $-5.74 *$ & $-5.74 *$ & $-4.68^{*}$ & \\
\hline
\end{tabular}

Note: This table presents summary statistics and selected normality, autocorrelation, and stationarity tests for domestic (panel A) and international (panel B) price return series for maize, rice, sorghum, and wheat. An asterisk indicates that the null hypothesis is rejected at the $5 \%$ level of confidence

and international price returns requires further examination, as will be discussed in the next section.

Table 13.1 provides some descriptive statistics for the domestic and international price returns used in the analysis. First, the Jarque-Bera test indicated that the returns for almost every domestic price and all four international prices did not follow a normal distribution. The kurtosis in all of the analyzed markets was greater than 3 , further pointing to a leptokurtic distribution of returns. These results revealed the need to use a Student's t density for the estimation of the BEKK models below.

Second, both the Ljung-Box (LB) statistics for up to five and ten lags and the Portmanteau (Q) statistics for the first- and second-order autocorrelation coefficients generally rejected the null hypothesis of no autocorrelation for the squared returns. 
This autocorrelation suggests the existence of nonlinear dependencies in several of the price returns, which motivates the use of MGARCH models to better capture own- and cross-market interdependencies between domestic and international markets.

Third, the Augmented Dickey-Fuller (ADF) test suggested that several of the domestic and international prices (in natural logarithms) were non-stationary. As explained in the methodology section, for all these cases, a cointegration test was first conducted to determine if a potential long-run relationship between the corresponding domestic and international price needs to be taken into account by applying a vector-error correction model. Finally, the ADF test confirms the stationarity of all the domestic and international price returns series.

\subsection{Results}

In this section, we describe our estimates of volatility transmission from international commodity markets to domestic food markets across countries and commodities. Due to space limitations, we did not provide detailed estimation results of the BEKK model for each of the 41 country-commodity combinations; instead, we assessed the reliability of our estimations by comparing model predictions to sample statistics. In particular, we compared the volatility of each domestic price sample (standard deviation of domestic price returns) with the corresponding predicted volatility from our estimated model. Since the BEKK model explicitly formulates a law of motion for the conditional variance of price returns, the estimated variance are not individual values but rather a series of monthly estimated conditional variances. In addition, we can estimate the implied steady-state (or unconditional) volatility and compare it with the sample volatility. In practice, we estimate the following for each domestic price return:

The sample volatility: $\left(h_{11}^{\text {sample }}\right)^{0.5}=\sqrt{\frac{\sum_{t=1}^{n}\left(r_{t}-\bar{r}\right)^{2}}{n}}$

The steady-state volatility $\left(h_{11}^{S S}\right)^{0.5}$ which satisfies the following expression: $H^{S S}=C^{\prime} C+G^{\prime} H^{S S} G$

The average of the predicted conditional volatilities: $\overline{\widehat{h_{11}}}=\frac{\sum_{t=1}^{n} \widehat{h}_{11 . t}^{0.5}}{n}$

Figure 13.5a-c compare the sample values and model estimates of the domestic price volatility. First, note that the sample volatilities of maize prices are, on average, higher than those of rice and wheat. The sample maize price volatilities ranged from $4.3 \%$ (in Mexico) to $20.8 \%$ (in Malawi), with an average of $10.4 \%$ for our full set of countries. Sorghum also showed volatility levels which are similar to or even higher than maize, although we only obtained data for three countries. In the case of rice and wheat, the sample volatilities are on average $4.7 \%$ and $4.8 \%$, respectively. Interestingly, African countries have the highest sample volatilities (an average of $11.3 \%$ ), while Asia and Latin America countries have averages which are less than half of the African average. 


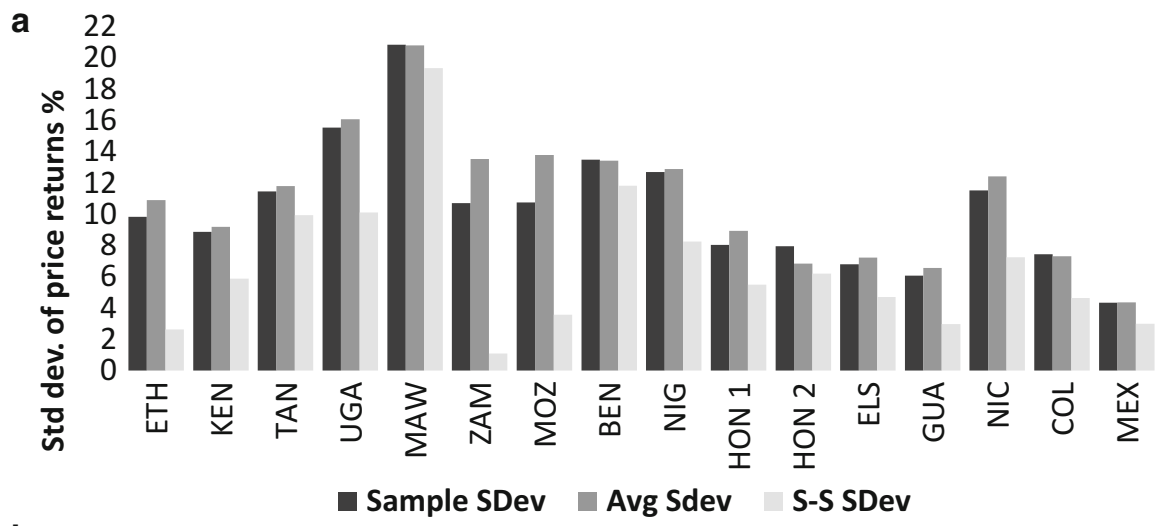

b

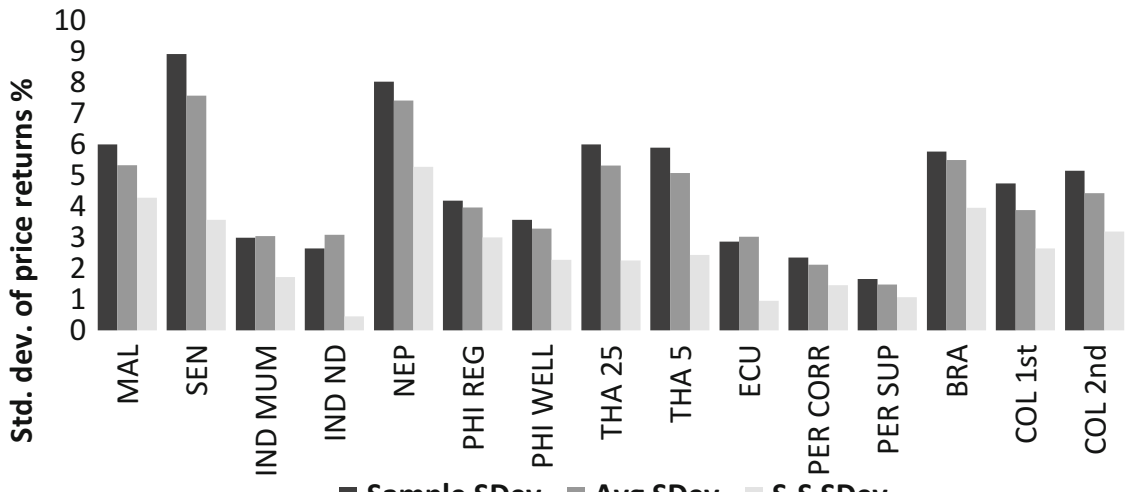

C

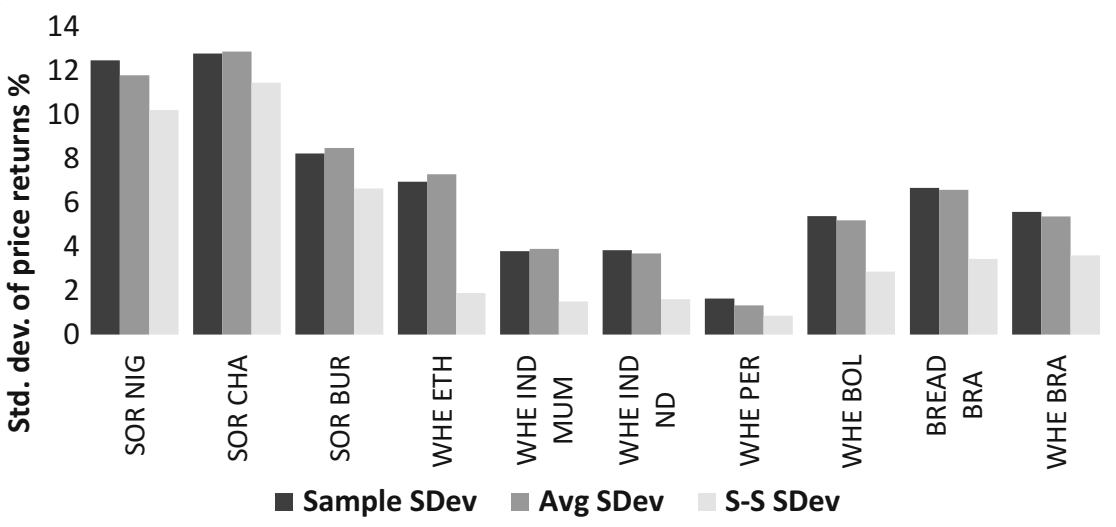

Fig. 13.5 Volatility of monthly prices (in \%) sample, average, and steady state for (a) maize, (b) rice, and (c) sorghum/wheat. Note: Figures (a)-(c) compare the sample, average, and steady-state volatilities of monthly price returns. Sample volatility is defined as the standard deviation of the domestic price returns. Average and steady-state volatilities were derived from the results of the conditional variance estimation. The average volatility is the average of the squared roots of the estimated domestic variance terms. The steady-state volatility is the squared root of the domestic variance term after the estimated system reaches a hypothetical steady state. See Sect. 13.5 of the main text for details. 
Our estimated steady-state and predicted volatilities yielded similar conclusions when comparing commodities and regions. On average, volatilities estimated by our model for maize prices are larger than those for rice and wheat, with the last two being quite similar. Across regions, estimated food price volatility was around twice as high in Africa than Asia and Latin America. Comparing steady-state volatility with sample volatility, the former is consistently lower than the latter. In particular, steady-state volatility estimates are on average $60 \%$ of the sample estimates, and these differences range from $10 \%$ for maize in Zambia to $93 \%$ for maize in Malawi. Steady-state estimates are expected to be consistently lower than sample estimates because steady-state estimates reflect the standard deviations to be reached over time in the absence of shocks to price volatility. This finding is also consistent with results reported by Gardebroek et al. (2014).

When comparing the average predicted volatility from the estimated models with the sample volatility, we also observed that our estimated models exhibited a relatively good predictive performance. The ratio of the average predicted volatility to the sample volatility is on average 0.99 for the full set of countries and commodities. This ratio ranged from 0.81 for wheat in Peru (the largest underestimation) to 1.28 for maize in Mozambique (the largest overestimation). Across commodities, the model predictions on average slightly overestimated the sample value in the case of maize (average ratio of 1.05) and underestimate it for rice and wheat (average ratios of 0.92 and 0.96 ). These average predicted volatilities further reaffirm that maize prices are much more volatile than rice and wheat prices.

To estimate the degree of volatility transmission from international markets to domestic markets, we carried out the following two steps for each estimated model (one per country-commodity):

We estimated the size of a shock in the international market $\left(\bar{\varepsilon}_{2}\right)$ such that the steady-state variance of the international price return increases by $1 \%$ after one period:

$$
\frac{H_{1,22}\left(\bar{\varepsilon}_{2}\right)-H_{0,22}}{H_{0,22}}=0.01
$$

We introduced the shock $\bar{\varepsilon}_{2}$ into Eq. (13.2), estimated the percentage change in the variance of the domestic price return (with respect to its steady-state value), and compute our volatility transmission VT indicator according to:

$$
\mathrm{VT}=\frac{H_{1,11}-H_{0,11}}{H_{0,11}} \div 0.01
$$

In other words, our volatility transmission indicator compares the reaction (after one period and assuming the system is at a steady state) of the domestic price return variance and the reaction of the international price return variance to a shock in the international market. If our volatility transmission indicator is equal to 1 , it means that the domestic price return variance increases by the same proportion as 

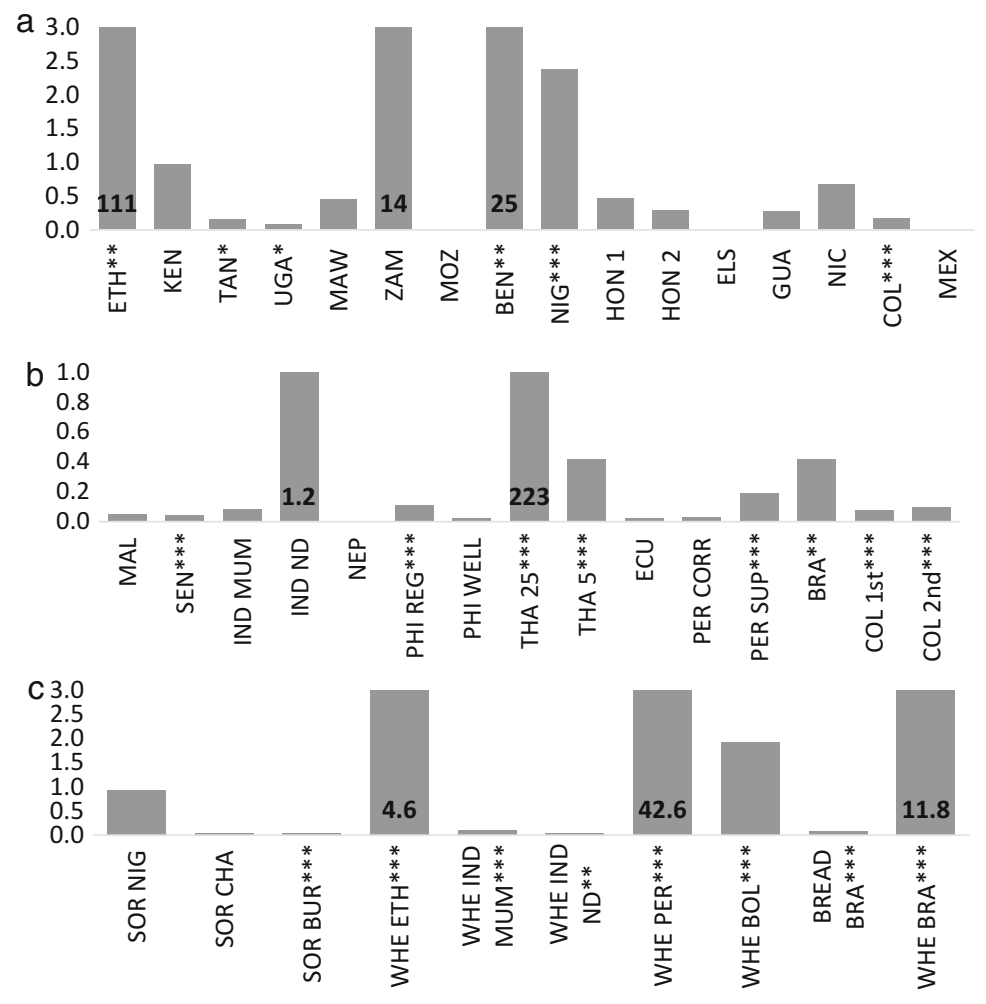

Fig. 13.6 Price return volatility transmission estimates for (a) maize, (b) rice, and (c) sorghum/wheat. Note: Figures (a)-(c) show estimates for the elasticity of price volatility transmission from international markets to domestic markets for each available country and commodity. Panel (a) focuses on volatility transmission of the international maize price, panel (b) on volatility transmission of the international price of rice, and panel (c) on volatility transmission of the international prices of sorghum (first three country-commodities) and wheat. The elasticity of price volatility is defined as the percentage change in the variance of the domestic price return (with respect to its steady-state value) relative to that of the international price return variance (see Sect. 13.5 of the main text for details). The figure is truncated to preserve scale; outlier values are indicated in bold. *, **, and *** denote statistically significant estimates at the $1 \%, 5 \%$, and $10 \%$ level, respectively

the international price return variance in one period, after introducing a shock to the international market.

We present our volatility transmission estimates for each country and commodity in Fig. 13.6a-c, together with a measure of their statistical significance. Aggregated medians and frequencies across commodities and regions are shown in Table 13.2. ${ }^{8}$

\footnotetext{
${ }^{8} \mathrm{We}$ measured statistical significance by implementing the Wald test for the joint significance of $\alpha_{21}$ and $g_{21}$ in the conditional variance equation, where $\alpha_{21}$ is the short-term effect of an
} 
Table 13.2 Price return volatility transmission, by commodity and region

\begin{tabular}{|c|c|c|c|c|c|c|}
\hline & \multirow[b]{2}{*}{ Median } & \multicolumn{4}{|c|}{ Volatility transmission (elasticity) } & \multirow[b]{2}{*}{$\begin{array}{l}\text { Not significant } \\
\text { (at } 5 \% \text { level) }\end{array}$} \\
\hline & & $\begin{array}{l}\text { Lower } \\
\text { than } 0.1\end{array}$ & $\begin{array}{l}\text { Between } \\
0.1 \text { and } 1\end{array}$ & $\begin{array}{l}\text { Higher } \\
\text { than } 1\end{array}$ & Total & \\
\hline Total & 0.172 & 6 & 6 & 8 & 20 & 21 \\
\hline \multicolumn{7}{|l|}{ By commodity } \\
\hline Maize & 0.372 & 0 & 1 & 3 & 4 & 12 \\
\hline Rice & 0.082 & 3 & 4 & 1 & 8 & 7 \\
\hline Sorghum & 0.035 & 1 & 0 & 0 & 1 & 2 \\
\hline Wheat & 1.919 & 2 & 1 & 4 & 7 & 0 \\
\hline \multicolumn{7}{|l|}{ By region } \\
\hline Africa & 0.450 & 2 & 0 & 4 & 6 & 9 \\
\hline Asia & 0.103 & 1 & 3 & 1 & 5 & 4 \\
\hline $\begin{array}{l}\text { Central America } \\
\text { and Caribbean }\end{array}$ & 0.288 & 0 & 0 & 0 & 0 & 6 \\
\hline South America & 0.172 & 3 & 3 & 3 & 9 & 2 \\
\hline
\end{tabular}

Note: This table shows the estimates of the elasticity of price volatility transmission from international markets to domestic markets by commodity and region. The first column presents the median elasticity of all estimates, while columns 2-4 show the number of statistically significant cases (at the $5 \%$ level) for which the estimated elasticity falls between certain values. The last column shows the number of cases for which the estimated volatility transmission was not statistically significant at the $5 \%$ level. The elasticity of price volatility is defined as the percentage change in the variance of the domestic price return (with respect to its steady-state value), relative to that of the international price return variance (see Sect. 13.5 of the main text for details)

Overall, we found volatility transmission that was statistically significant at the $5 \%$ level in about half of the cases, with most of the estimates within reasonable values. ${ }^{9}$

In the case of maize, the median volatility transmission from international to domestic markets was 0.37 , but just 4 of the 16 countries exhibited a relationship that is significant at the $5 \%$ level: Ethiopia, Benin, Nigeria, and Colombia.

Our estimates indicated that the volatility transmission of rice prices was lower than that of maize and wheat. The median volatility transmission was less than 0.1 , and in seven out of eight statistically significant cases, our volatility transmission estimates are below 0.5. On the other hand, more than half of the estimates of volatility transmission for rice are statistically significant, compared to just onefourth for maize. Across regions, evidence of transmission was observed mostly in Asia and Latin America, with the highest levels in Thailand and Brazil.

international price shock on domestic volatility (innovation effect) and $g_{21}$ is the short-term effect of changes in international price volatility on domestic volatility (persistence effect).

${ }^{9}$ Our estimates showed extreme values larger than 10 only in 6 of the 41 cases. 
In the case of wheat, the median volatility transmission (1.92) is larger than for any other commodity, and all of our estimates are statistically significant. However, there does not seem to be a clear pattern across countries. Volatility transmission was very low (below 0.2) in three of the seven cases: Mumbai wheat, New Delhi wheat, and Brazilian bread. In contrast, volatility transmission was quite high (above 4) in three other cases: wheat in Peru, Brazil, and Ethiopia. Finally, volatility transmission for sorghum was estimated for just three economies, all in Africa, and only one of these (Burkina Faso) was statistically significant.

In terms of regional patterns, while we found no evidence of price volatility transmission in any Central American and Caribbean countries, there was a significant relationship between the volatility of international prices and domestic prices in a large proportion of South American economies. In the case of Africa and Asia, the evidence was mixed, with statistically significant volatility transmission in around one-third of the African cases and one-half of the Asian cases.

\subsection{Discussion}

We expect price transmission and volatility transmission to be greatest when (1) the international trade in the commodity is large relative to domestic production or consumption, (2) trade restrictions (particularly quantitative restrictions) are low, (3) the government does not intervene to stabilize the domestic price of the commodity, and (4) the transport costs between the country and international markets are low. Some of these factors, particularly the ratio of trade to domestic production, are helpful in explaining the volatility transmission results obtained in this study, but some of the findings were unexpected.

In the case of maize, it is unsurprising that Colombia was the only Latin American country for which our estimate of volatility transmission was statistically significant: Colombian maize imports are equivalent to $64 \%$ of its domestic production, as shown in Appendix Table 13.5. In the other five Latin American countries, the proportion ranges from $15 \%$ to $38 \%$. And the African countries are not expected to have statistically significant volatility transmission because they are almost self-sufficient in maize production (net trade is 0-9\% of domestic production). The only unexpected finding was the statistically significant volatility transmission in Ethiopia, Nigeria, and Benin.

Turning to rice markets, it is unsurprising that volatility transmission was statistically significant in Thailand, which exports $70 \%$ of its domestic rice production, and Senegal, whose imports are equivalent to $82 \%$ of its domestic output (see Appendix Table 13.5). The lack of volatility transmission to domestic markets in Mali, India, Nepal, and Ecuador is expected given that these countries import an equivalent of no more than $16 \%$ of their domestic production. However, there was evidence of volatility transmission to the domestic markets of Peru, Brazil, and Colombia despite these countries relying minimally on rice imports. 
In the case of sorghum, the three countries examined have negligible trade in this commodity, so the volatility transmission in Burundi was unexpected, but the lack of transmission in the other two countries was expected.

As mentioned above, all of the seven wheat prices tested showed statistically significant transmission of volatility. This was expected in the cases of Peru, Bolivia, and Brazil, whose wheat imports are equivalent to $88 \%, 72 \%$, and $56 \%$ of domestic production, respectively. And it is perhaps also understandable in the case of Ethiopia, whose imports are equivalent to $32 \%$ of domestic output. However, it is less clear why international volatility is transmitted to Indian wheat markets given that wheat trade is equivalent to just $2 \%$ of its domestic production.

Overall, it appears that price volatility is (is not) transmitted from international to domestic markets when the ratio of traded volume to domestic production is above (below) $40 \%$. In our analysis, 29 of the 41 prices (71\%) follow this pattern.

\subsection{Conclusions}

Food price volatility in developing countries is economically and politically important. In these economies a large share of household budgets is spent on food, so food price levels and volatility have a direct and large impact on welfare. Food price volatility also affects poor, small-scale farmers who rely on crop sales for a significant part of their income. Food price volatility is also likely to inhibit agricultural investment and reduce the growth in agricultural productivity, with long-run implications for poor consumers and farmers. Hence, it is important to better understand the sources of food price volatility and whether the volatility is mostly transmitted from international agricultural commodity markets or largely determined by domestic factors. This in turn will help design better global, regional, and domestic policies to cope with excessive food price volatility and to protect the most vulnerable groups.

The objective of this paper is to estimate the transmission of grain price volatility from world markets to local markets in developing countries, as these estimates have been generally absent in the literature. In particular, we focused on the effect of the world price of maize, rice, wheat, and sorghum on 41 prices of grain products in 27 countries across Latin America, Africa, and Asia. Monthly price data were used, and the data mostly covered the period from January 2000 to December 2013. The analysis was based on a MGARCH approach using a BEKK model.

We assessed the reliability of our estimations by comparing model predictions to sample statistics. In particular, we compared sample food price volatility to average predicted conditional volatility and estimated steady-state volatility. Our model predictions did a good job in replicating sample data patterns. For our full set of commodity/countries, the ratio of the average predicted volatility to the sample volatility was 0.99 , and as in the data, the average predicted volatility is higher for 
maize prices than for rice and wheat prices. Across regions, the estimates showed that the average food price volatility in African countries was around double those in South Asia and Latin America. Furthermore, as expected, our estimated steady-state price volatilities were consistently lower than the sample price volatilities.

We proposed a volatility transmission estimator (or elasticity) that shows the reaction of domestic price return variance relative to the reaction of international price return variance to a one-time shock in the international market (after one period and assuming the system is at steady-state).

We found that most of our estimates were within reasonable values. About half (20 of 41) of the volatility transmission estimates were statistically significant, but the proportion varies by commodity: all seven wheat prices show volatility transmission, but just half of the rice prices and one-fourth of the maize prices did so. Volatility transmission of a commodity's price appears to be linked to the importance of trade in that commodity to the country in question. When the ratio of trade to domestic production is over (under) $40 \%$, price volatility is (is not) transmitted from world markets to local markets. This rule could explain 29 of the 41 prices examined $(71 \%)$. All 12 exceptions to this rule are cases in which trade is minimal but volatility is transmitted from world markets. This could occur through transmission of volatility between closely related commodity markets or perhaps as a result of transmission of "anxiety" from international markets to domestic markets. Further research is needed to examine these alternative explanations.

Acknowledgements The authors acknowledge funding from the European Commission within the FoodSecure Research Project.

\section{Appendix}




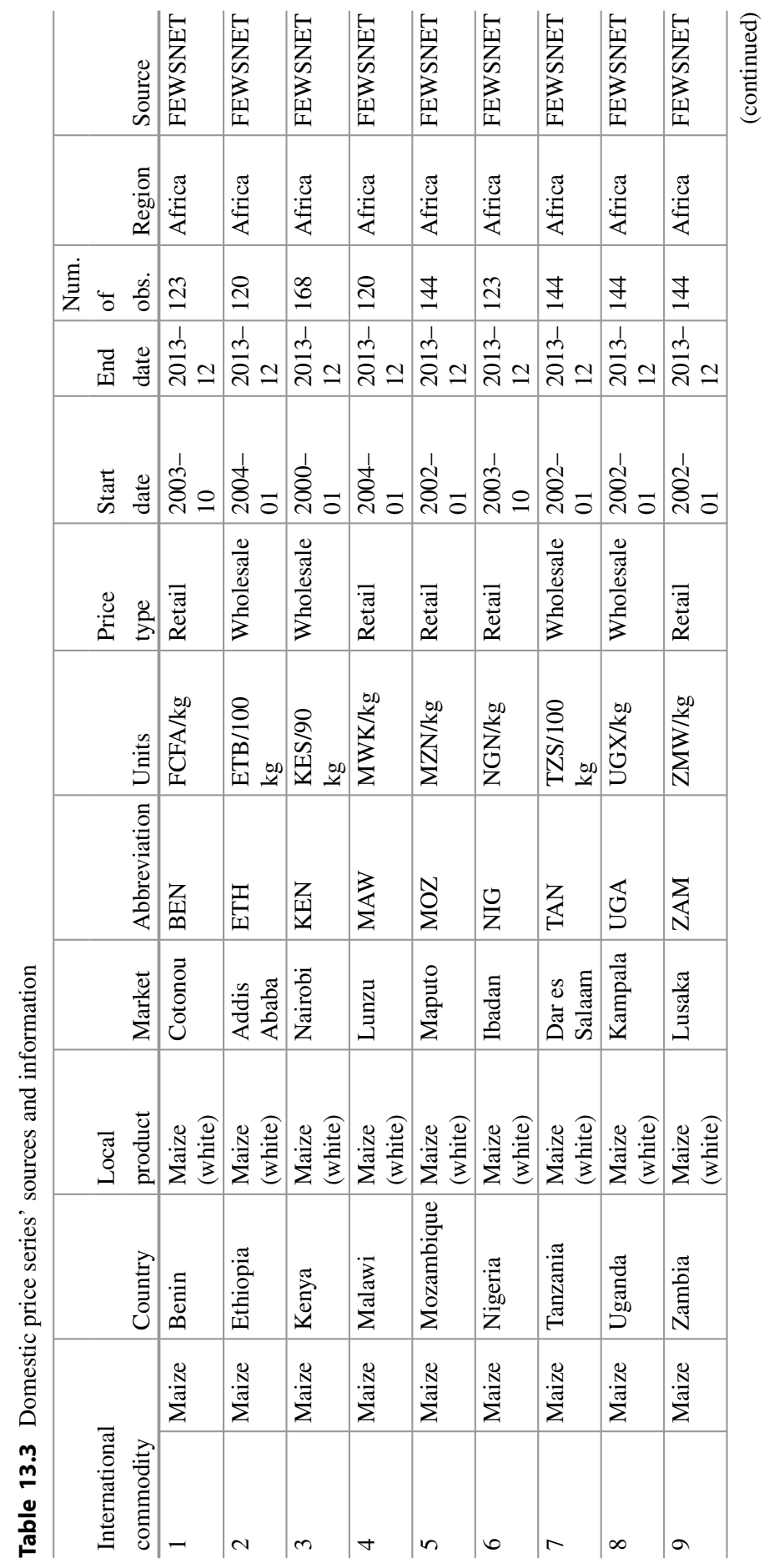




\begin{tabular}{|c|c|c|c|c|c|c|}
\hline $\begin{array}{l} \\
\mathscr{E} \\
: \\
:\end{array}$ & 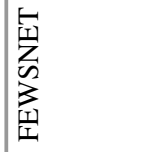 & 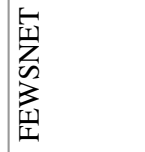 & 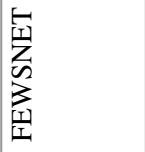 & 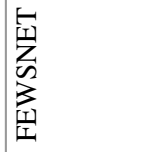 & 綮 & 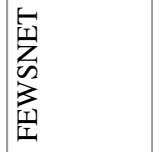 \\
\hline 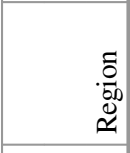 & 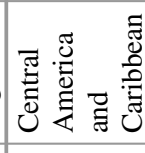 & 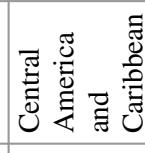 & 焉莺 & 胥 & 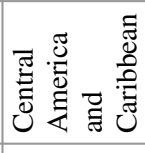 & 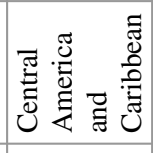 \\
\hline$\dot{\bar{z}}$ & $\underline{0}$ & $\bar{\Xi}$ & $\stackrel{\infty}{ \pm}$ & $\stackrel{\infty}{ \pm}$ & $\Xi$ & $\overline{0}$ \\
\hline 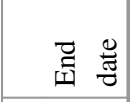 & $\frac{1}{\stackrel{d}{a}} \simeq$ & $\frac{1}{\partial} \underset{d}{d} \simeq$ & $\frac{1}{\partial} \stackrel{d}{a} \simeq$ & $\frac{1}{\stackrel{2}{a}} \simeq$ & $\frac{d}{8} 8$ & $\frac{1}{\stackrel{d}{a}} \simeq$ \\
\hline 䭴 & ¿ें & 吕 & $\frac{1}{8} 8$ & $\frac{1}{8} 8$ & 离 & 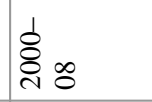 \\
\hline$\stackrel{\mathscr{E}}{2}$ & 苞 & 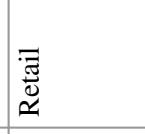 & 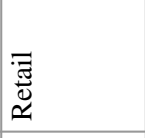 & 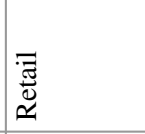 & 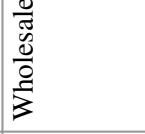 & 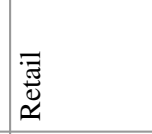 \\
\hline$\stackrel{气}{5}$ & 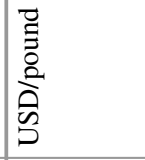 & $\begin{array}{l}\bar{Z} \\
\vdots \\
0 \\
2 \\
0 \\
0 \\
0\end{array}$ & 说竞 & 号竞 & 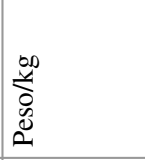 & 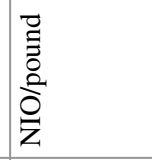 \\
\hline $\begin{array}{l}3 \\
. \overline{0} \\
\frac{0}{0} \\
\frac{0}{0} \\
\frac{0}{4}\end{array}$ & 盗 & 䓌 & $\begin{array}{l}\vec{z} \\
\text { Oz } \\
\text { I }\end{array}$ & r & $\stackrel{x}{i}$ & $\bar{z}$ \\
\hline 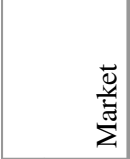 & 童 & 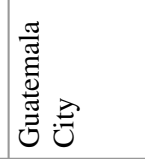 & 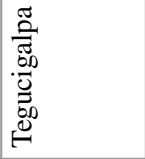 & 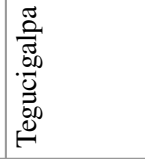 & 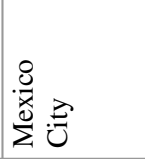 & 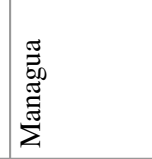 \\
\hline 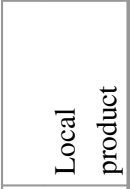 & 总氪 & 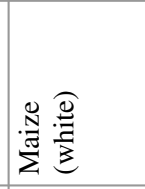 & 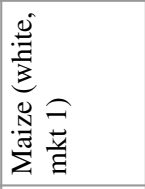 & 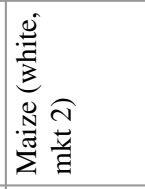 & 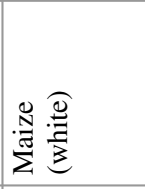 & 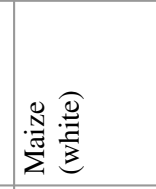 \\
\hline 己े & 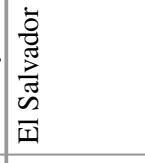 & 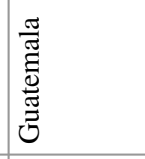 & 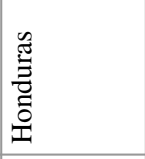 & 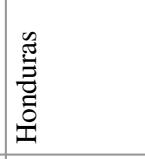 & 这 & 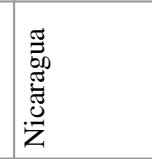 \\
\hline 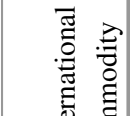 & : & 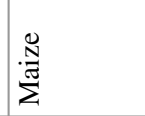 & 离 & 节 & 芯 & 葛 \\
\hline$\stackrel{\mathscr{Q}}{\Xi}$ & 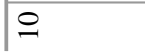 & $=$ & $\simeq$ & 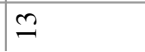 & \pm & $\simeq$ \\
\hline
\end{tabular}




\begin{tabular}{|c|c|c|c|c|c|c|c|c|c|c|}
\hline 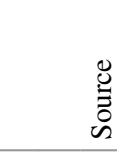 & 泴 & 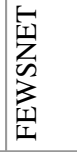 & 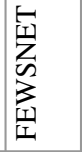 & $\begin{array}{l}2 \\
3 \\
1 \\
0 \\
0\end{array}$ & $\begin{array}{l}n \\
j \\
1 \\
0 \\
0\end{array}$ & 泴 & $\begin{array}{l}n \\
3 \\
1 \\
0 \\
0\end{array}$ & $\begin{array}{l}n \\
j \\
1 \\
0 \\
0\end{array}$ & 睩 & 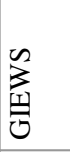 \\
\hline $\begin{array}{l}\tilde{0} \\
.00 \\
\mathscr{0}\end{array}$ & 吾离 & $\stackrel{\mathscr{C}}{\mathscr{E}}$ & 莺 & $\frac{. \pi}{2}$ & $\frac{. \pi}{2}$ & $\frac{\cdot \pi}{2}$ & $\frac{. \pi}{2}$ & $\frac{\cdot \pi}{2}$ & $\frac{. \pi}{2}$ & $\cdot \frac{\pi}{2}$ \\
\hline 豆 & $\stackrel{ \pm}{n}$ & ป & $\bar{\beth}$ & $\Xi$ & $\Xi$ & $\stackrel{ }{=}$ & $\stackrel{9}{I}$ & $\stackrel{9}{I}$ & $\stackrel{9}{I}$ & $\stackrel{2}{I}$ \\
\hline تี్ّี & $\stackrel{1}{\stackrel{1}{2}}$ & $\stackrel{\frac{1}{2}}{\stackrel{2}{\curvearrowright} \simeq}$ & $\stackrel{1}{\stackrel{n}{c}} \varrho$ & $\stackrel{+}{\frac{1}{8}}$ & $\frac{1}{d}$ & $\frac{d}{d}$ & $\frac{1}{d}$ & $\frac{1}{d}$ & $\stackrel{+}{\stackrel{d}{*}}$ & $\frac{\frac{1}{d}}{\stackrel{d}{\delta}}$ \\
\hline 莺 & $\frac{1}{8}$ & ঠి & 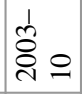 & o & @) & ¿ें & 方 & 离 & 方 & $\stackrel{1}{8}$ \\
\hline$\stackrel{\circlearrowright}{\Xi}$ & $\begin{array}{l}\frac{0}{\tilde{J}} \\
\frac{0}{0} \\
\frac{0}{3} \\
\frac{2}{3}\end{array}$ & 胥 & 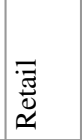 & 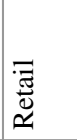 & 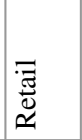 & 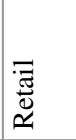 & 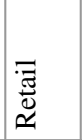 & 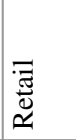 & $\begin{array}{l}\frac{0}{3} \\
\frac{3}{0} \\
\frac{0}{0} \\
\frac{1}{3}\end{array}$ & $\begin{array}{l}\frac{0}{\pi} \\
\frac{0}{0} \\
\frac{0}{0} \\
\frac{1}{3}\end{array}$ \\
\hline$\stackrel{\mathscr{0}}{\mathrm{g}}$ & 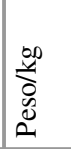 & 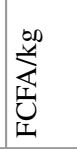 & 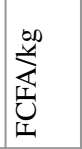 & 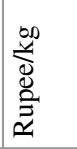 & 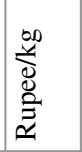 & 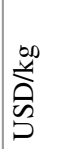 & 袈 & 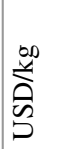 & 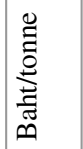 & 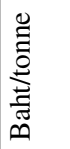 \\
\hline 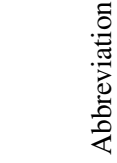 & ن & $\sum^{2}$ & 斍 & 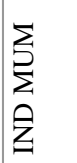 & 豆 & 牙 & 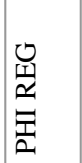 & 光 & 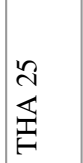 & $\underset{\underbrace{}}{\mathbb{E}}$ \\
\hline $\begin{array}{l}\overline{\mathrm{e}} \\
\overline{\bar{z}}\end{array}$ & $\begin{array}{l}\frac{1 \pi}{0} \\
0 \\
00 \\
0 \\
0\end{array}$ & 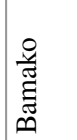 & 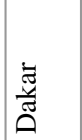 & 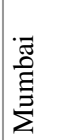 & z & 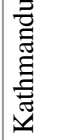 & 迹 $\frac{\pi}{3}$ & 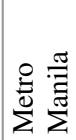 & 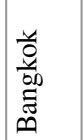 & $\begin{array}{l}\frac{1}{0} \\
\frac{0}{00} \\
\text { స్ } \\
\infty\end{array}$ \\
\hline 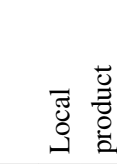 & 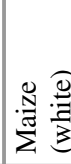 & 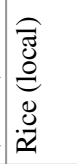 & 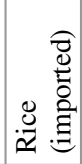 & 胥 & 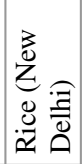 & 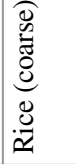 & 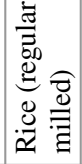 & 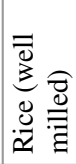 & 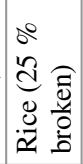 & 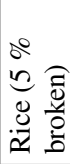 \\
\hline 兽 & ن & $\sum_{\Sigma}^{-7}$ & 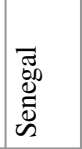 & $\stackrel{\overbrace =}{g}$ & 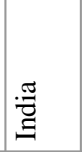 & $\begin{array}{l}\overline{\tilde{a}} \\
\overline{0} \\
\text { z }\end{array}$ & 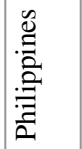 & 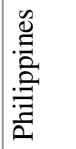 & 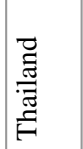 & 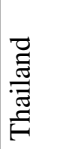 \\
\hline \multirow{2}{*}{ 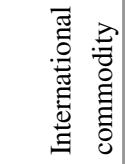 } & $\stackrel{\tilde{N}}{\tilde{\Xi}}$ & $\frac{\mathscr{U}}{\alpha}$ & $\frac{0}{2}$ & $\frac{\mathscr{U}}{\alpha}$ & $\frac{8}{20}$ & $\frac{\mathscr{u}}{2}$ & $\frac{\ddot{n}}{2}$ & $\frac{\ddot{U}}{2}$ & $\ddot{\mathscr{u}}$ & $\frac{8}{2}$ \\
\hline & 0 & $I$ & $\infty$ & 9 & ๙ి & $\bar{\sim}$ & त & $\ddot{\imath}$ & $\stackrel{\sim}{\sim}$ & $\stackrel{\sim}{2}$ \\
\hline
\end{tabular}




\begin{tabular}{|c|c|c|c|c|c|c|c|c|c|c|}
\hline $\begin{array}{l}\mathscr{0} \\
\stackrel{0}{0} \\
\dot{2}\end{array}$ & 㫌 & 先 & 綮 & 焦 & 告 & 倠 & 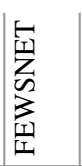 & 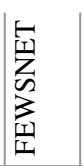 & 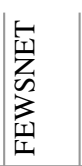 & 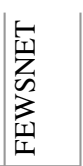 \\
\hline 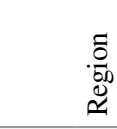 & 吾 & 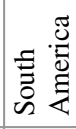 & 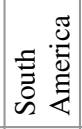 & 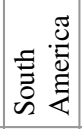 & 吾莺 & 吾泀 & $\stackrel{\mathscr{g}}{\mathbb{E}}$ & 葛 & 莺 & $\frac{\pi}{0}$ \\
\hline 㐏 & $\Xi$ & $I$ & $\Xi$ & $\Xi$ & 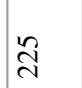 & 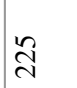 & $\hat{\beth}$ & $\exists$ & $\Xi$ & 이 \\
\hline ت્|ี & $\stackrel{+}{\stackrel{d}{2}}$ & $\stackrel{+}{ \pm}$ & $\frac{1}{\partial}$ & $\stackrel{+}{\stackrel{d}{\sigma}}$ & $\frac{1}{2}$ & $\stackrel{1}{\frac{1}{2}} 8$ & $\frac{1}{\stackrel{n}{2}} \simeq$ & $\frac{1}{\stackrel{d}{d}} \simeq$ & $\frac{1}{\partial} \underset{d}{d} \simeq$ & $\frac{1}{2} \stackrel{i}{2} \simeq$ \\
\hline 壳 & 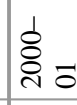 & ஓं & 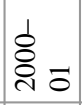 & 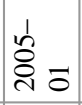 & 光 & 光 & ঠి & 尚 & 竎 & \&े \\
\hline$\stackrel{\circlearrowright}{\Xi}$ & 离 & $\begin{array}{l}\frac{0}{\tilde{J}} \\
\frac{0}{0} \\
\frac{0}{0} \\
\frac{0}{3}\end{array}$ & 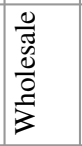 & $\begin{array}{l}\frac{0}{\tilde{J}} \\
\frac{0}{0} \\
\frac{0}{0} \\
\bar{z}\end{array}$ & 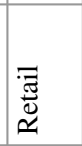 & 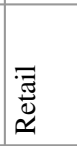 & : & : & : & $\begin{array}{l}\frac{0}{\tilde{J}} \\
\frac{0}{0} \\
\frac{0}{0} \\
3 \\
3\end{array}$ \\
\hline$\stackrel{\mathscr{B}}{5}$ & 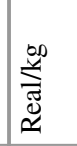 & 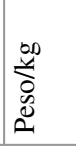 & 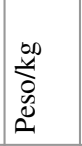 & 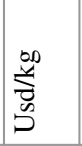 & 离 & 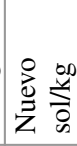 & $\sum_{\substack{\infty \\
⿱ 亠 䒑}}^{\infty}$ & 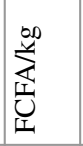 & $\begin{array}{l}\stackrel{0}{y} \\
\stackrel{y}{Z} \\
0 \\
Z\end{array}$ & 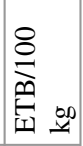 \\
\hline 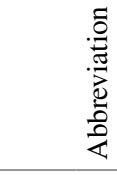 & $\frac{\mathbb{2}}{\infty}$ & $\begin{array}{l}\vec{w} \\
\vdots \\
0 \\
0 \\
0\end{array}$ & $\begin{array}{l}\vec{Z} \\
\text { ते } \\
\overrightarrow{0} \\
ن\end{array}$ & 己 & 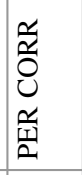 & 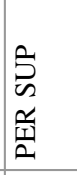 & 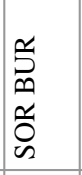 & 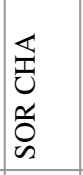 & 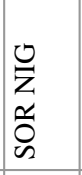 & 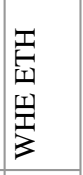 \\
\hline 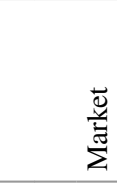 & 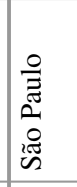 & $\begin{array}{l}10 \\
0 \\
0 \\
0 \\
0 \\
0\end{array}$ & $\begin{array}{l}\text { 营 } \\
8 \\
0 \\
0 \\
0\end{array}$ & $\stackrel{\circ}{\circ}$ &.$\stackrel{\mathscr{a}}{g}$ & 节 & 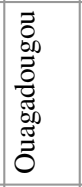 & 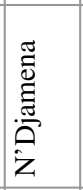 & 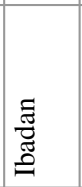 & 告 \\
\hline 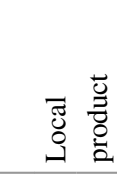 & $\frac{8}{2}$ & 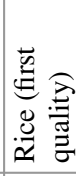 & 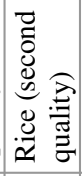 & 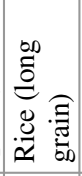 & 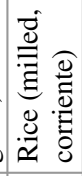 & 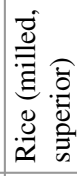 & 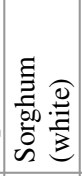 & 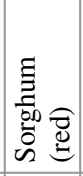 & 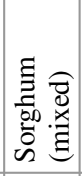 & $\frac{\vec{\Phi}}{3}$ \\
\hline $\begin{array}{l}\vec{E} \\
\text { Eे }\end{array}$ & : & $\begin{array}{l}\frac{\pi}{0} \\
\frac{0}{0} \\
\frac{0}{0} \\
0\end{array}$ & ن & 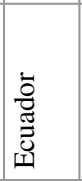 & 吾 & ᄅ্তু & 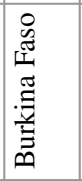 & 胥 & $\begin{array}{l}\cdot \frac{\pi}{\bar{D}} \\
.00 \\
\frac{.00}{Z}\end{array}$ & 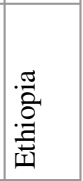 \\
\hline \multirow{2}{*}{ 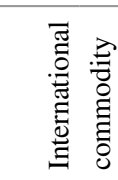 } & $\ddot{g}$ & $\frac{\ddot{y}}{\not \alpha}$ & . & $\stackrel{\mathscr{x}}{\underline{\alpha}}$ & $\stackrel{\mathscr{x}}{\underline{\alpha}}$ & $\stackrel{\ddot{x}}{\not{x}}$ & 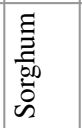 & 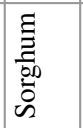 & 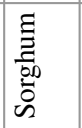 & $\frac{\vec{E}}{\stackrel{E}{*}}$ \\
\hline & i & $\hat{\sim}$ & $\stackrel{\infty}{\sim}$ & নे & in & $\bar{m}$ & n & $m$ & m & $m$ \\
\hline
\end{tabular}




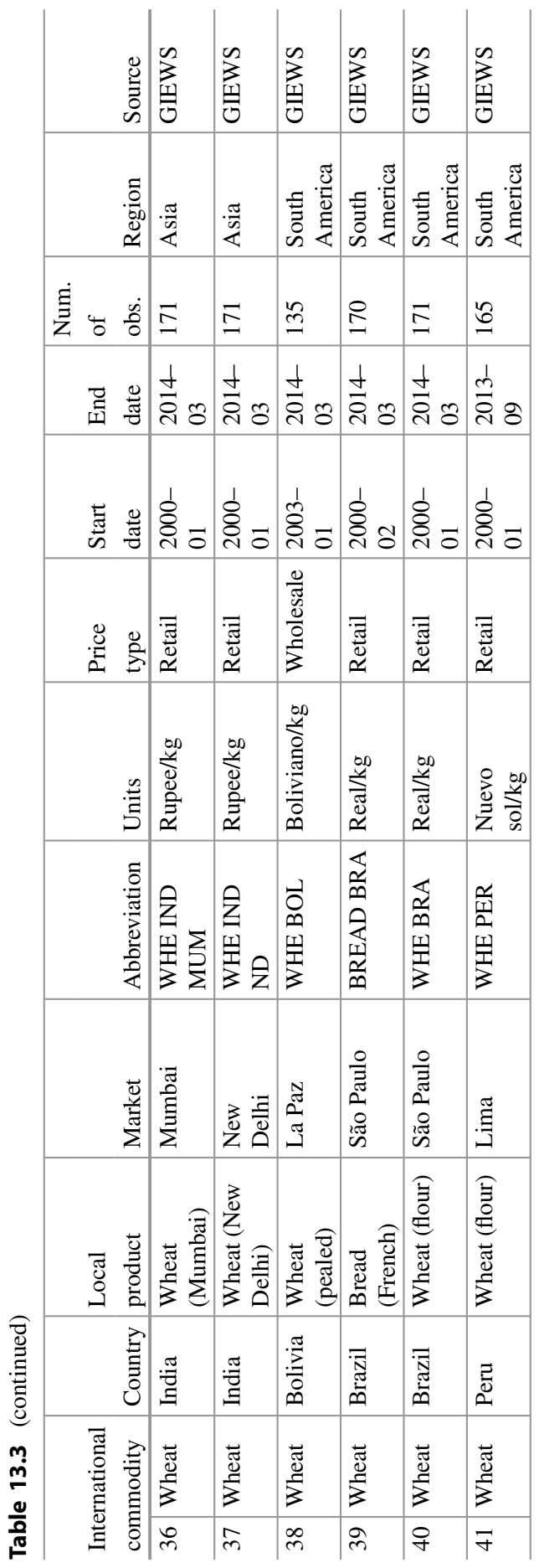


Table 13.4 International price series' sources and information

\begin{tabular}{l|l|l|l|l|l}
\hline $\begin{array}{l}\text { International } \\
\text { commodity }\end{array}$ & Description & Country & Market & Units & Source \\
\hline Maize & No. 2 yellow & United States & U.S. Gulf & US\$/tonne & $\begin{array}{l}\text { FAOSTAT (primary } \\
\text { source: USDA) }\end{array}$ \\
\hline Rice & $\begin{array}{l}\text { A1 super, } \\
\text { white broken }\end{array}$ & Thailand & Bangkok & US\$/tonne & $\begin{array}{l}\text { FAOSTAT (primary } \\
\text { source: Jackson Son } \\
\& \text { Co. (London) } \\
\text { Ltd.) }\end{array}$ \\
\hline Sorghum & No. 2 yellow & United States & U.S. Gulf & US\$/tonne & $\begin{array}{l}\text { FAOSTAT (primary } \\
\text { source: USDA) }\end{array}$ \\
\hline Wheat & $\begin{array}{l}\text { No. } 2 \text { hard } \\
\text { red winter }\end{array}$ & United States & U.S. Gulf & US\$/tonne & $\begin{array}{l}\text { FAOSTAT (primary } \\
\text { source: International } \\
\text { Grains Council) }\end{array}$ \\
\hline
\end{tabular}

Table 13.5 Ratio of imports minus exports over domestic production, average 2007-2013

\begin{tabular}{|c|c|c|c|c|}
\hline & Maize (\%) & Rice (\%) & Sorghum (\%) & Wheat (\%) \\
\hline Benin & 0 & 85 & 0 & 95 \\
\hline Chad & 8 & 2 & 4 & 91 \\
\hline Ethiopia & 1 & 49 & 3 & 32 \\
\hline Kenya & 9 & 86 & 10 & 70 \\
\hline Malawi & 0 & 3 & 8 & 108 \\
\hline Mali & 1 & 16 & 0 & 103 \\
\hline Mozambique & 9 & 77 & 1 & 95 \\
\hline Nigeria & 0 & 37 & 0 & 98 \\
\hline Senegal & 30 & 82 & 1 & 100 \\
\hline Tanzania & 0 & 9 & 0 & 100 \\
\hline Uganda & -2 & 29 & 7 & 94 \\
\hline Zambia & -7 & 46 & 35 & 10 \\
\hline India & -13 & -5 & -1 & -2 \\
\hline Nepal & 3 & 5 & 109 & 1 \\
\hline Philippines & 4 & 12 & 97 & 104 \\
\hline Thailand & -6 & -70 & -3 & 105 \\
\hline Bolivia & 1 & 3 & -1 & 72 \\
\hline Brazil & -18 & 3 & -1 & 56 \\
\hline Colombia & 64 & 6 & 52 & 98 \\
\hline Ecuador & 33 & -5 & 44 & 100 \\
\hline El Salvador & 38 & 72 & 1 & 100 \\
\hline Guatemala & 32 & 71 & 0 & 97 \\
\hline Honduras & 37 & 83 & 1 & 97 \\
\hline Mexico & 25 & 76 & 32 & 44 \\
\hline Nicaragua & 15 & 35 & -1 & 100 \\
\hline Peru & 50 & 5 & 99 & 88 \\
\hline Mean abs. value & 16 & 36 & 22 & 72 \\
\hline
\end{tabular}

Note: Data obtained from FAOSTAT online (accessed on May, 2015) 
Open Access This chapter is distributed under the terms of the Creative Commons AttributionNoncommercial 2.5 License (http://creativecommons.org/licenses/by-nc/2.5/) which permits any noncommercial use, distribution, and reproduction in any medium, provided the original author(s) and source are credited.

The images or other third party material in this chapter are included in the work's Creative Commons license, unless indicated otherwise in the credit line; if such material is not included in the work's Creative Commons license and the respective action is not permitted by statutory regulation, users will need to obtain permission from the license holder to duplicate, adapt or reproduce the material.

\section{References}

Abdulai A (2000) Spatial price transmission and asymmetry in the Ghanaian maize market. J Dev Econ 63:327-349

Ai C, Chatrath A, Song F (2006) On the co-movement of commodity prices. Am J Agric Econ 88:574-588

Baba Y, Engle R, Kraft D, Kroner KF (1990) Multivariate simultaneous generalized ARCH. Department of Economics, University of California, San Diego, Mimeo

Baulch B (1997) Transfer costs, spatial arbitrage and testing for food market integration. Am J Agric Econ 79:477-487

Bauwens L, Laurent S, Rombouts JVK (2006) Multivariate GARCH models: a survey. J Appl Econ 21:79-109

Beckmann J, Czudaj R (2014) Volatility transmission in agricultural futures markets. Econ Model 36:541-546

Conforti P (2004) Price transmission in selected agricultural markets. Commodity and Trade Policy Research Working Paper No 7. Food and Agriculture Organisation, Rome

Deb P, Trivedi PK, Varangis P (1996) The excess co-movement of commodity prices reconsidered. J Appl Econ 11:275-291

Engle R, Kroner FK (1995) Dynamic conditional correlation - a simple class of multivariate GARCH models. J Bus Econ Stat 20:339-350

Gallagher L, Twomey C (1998) Identifying the source of mean and volatility spillovers in Irish equities: a multivariate GARCH analysis. Econ Soc Rev 29:341-356

Gardebroek C, Hernandez MA (2013) Do energy prices stimulate food price volatility? Examining volatility transmission between US oil, ethanol and corn market. Energy Econ 40:119-129

Gardebroek C, Hernandez MA, Robles M (2015) Market interdependence and volatility transmission among major crops. Agric Econ. Advance online publication. doi: 10.1111/agec.12184

Gilbert CL (2010) How to understand high food prices. J Agric Econ 61:398-425

Hernandez MA, Ibarra R, Trupkin DR (2014) How far do shocks move across borders? Examining volatility transmission in major agricultural futures markets. Eur Rev Agric Econ 41(2):301325

Le Pen Y, Sévi B (2010) Revisiting the excess co-movement of commodity prices in a data rich environment. Economics Papers from University Paris Dauphine, Paris Dauphine University, France

Lutz C, Kuiper WE, van Tilburg A (2006) Maize market liberalisation in Benin: a case of hysteresis. J Afr Econ 16(1):102-133

Meyer J, von Cramon-Taubadel S (2004) Asymmetric price transmission: a survey. J Agric Econ 55(3):581-611

Minot N (2010) Transmission of World food price changes to African markets and its effect on household welfare. IFPRI discussion papers 1059. International Food Policy Research Institute, Washington, DC

Minot N (2014) Food price volatility in sub-Saharan Africa: has it really increased? Food Policy 45:45-56 
Moser C, Barrett C, Minten B (2009) Spatial integration at multiple scales: rice markets in Madagascar. Agric Econ 40:281-294

Mundlak Y, Larson D (1992) On the transmission of world agricultural prices. World Bank Econ Rev 6(3):399-422

Myers R (2008) Evaluating the efficiency of inter-regional trade and storage in Malawi maize markets. Report for the World Bank. Michigan State University, East Lansing, MI

Negassa A, Myers R (2007) Estimating policy effects on spatial market efficiency: an extension to the parity bounds model. Am J Agric Econ 89:338-352

Pindyck RS, Rotemberg JJ (1990) The excess co-movement of commodity prices. Econ J 100:1173-1189

Quiroz J, Soto R (1995) International price signals in agricultural prices: do governments care? Documento de investigacion 88. ILADES Postgraduate Economics Program, Georgetown University, Santiago, Chile

Rashid S (2004) Spatial integration of maize markets in post-liberalised Uganda. J Afr Econ 13(1):102-133

Saadi H (2010) Price co-movement in international markets and their impacts on price dynamics. In: Piot-Lepetit I, M'Barek R (eds) Methods to analyse agricultural commodity price volatility. Springer Science, Berlin, pp 149-163

Seale JL, Regmi A, Bernstein J (2003) International evidence on food consumption patterns. Technical Bulletin No. 33580. United States Department of Agriculture, Economic Research Service

Silvennoinen A, Teräsvirta T (2009) Multivariate GARCH models. In: Andersen TG, Davis RA, Kreiß J-P, Mikosch T (eds) Handbook of financial time series. Springer, Berlin, pp 201-229

Van Campenhout B (2007) Modeling trends in food market integration: method and an application to Tanzanian maize markets. Food Policy 32:112-127

Zhao J, Goodwin B (2011) Volatility spillovers in agricultural commodity markets: an application involving implied volatilities from options markets. Paper prepared for presentation at the Agricultural and Applied Economics Association's 2011 Annual Meeting 